\title{
Relationship on Nursing Performance of Patient Satisfaction in Installation of Hospital in General Hospital Deli Serdang Region
}

\author{
Ruth Merry Simorangkir ${ }^{1}$, Thomson ${ }^{2}$, Anto. J. Hadi ${ }^{2}$ \\ ruthsimorangkir77@gmail.com
}

\author{
${ }^{1}$ MRS Master Student, Faculty of Public Health, Helvetia Health Institute, Indonesia \\ ${ }^{2}$ Lecturer for Master of MRS, Faculty of Public Health, Helvetia Institute of Health, \\ Indonesia
}

Received: January 21, 2021

Received in Revised: February 24,

Accepted: March 8, 2021 2021

\begin{abstract}
Patients assess the efficiency of nursing care by the fulfillment of their desires. This thesis was to identify the correlation between nurses' inpatient service quality and patient satisfaction. quantitative and cross-sectional research This sample was made up of all patients admitted to the Deli Serdang Hospital, which indicates that about 320 patients were hospitalized for [for an average of] 3 days. 5 days. as many as 77 human population samples of which were chosen to be included in the study All data derived from interviews and observations using a statistical model with a 5\% significance level of probability, evaluated using the Multiple Linear Regression Approach The multiple logistic statistical evidence indicates that the influence of the vector service efficiency $(p=0.016)$ and connectivity $(p=0.016)$ is important $(p=0.043)$ on patient satisfaction. The level of contact has the biggest impact on patient satisfaction at the general ward in the Dedun restorative In-Patient Deli Serdang Hospital The results of this study are that service quality, connectivity, tempo, and capacity have an impact on customer satisfaction.
\end{abstract}

Keywords: The Performance of Nurse, Patient Satisfaction, Efficiency

\section{Introduction}

Hospital is both offers health care and creates an open networks that aim for complex harmony with the world around it. are linked to the primary goals of supplying healthcare to the community as well as a location for study (Aditama, 2002). Informal nursing care dealing with patients, families, and neighborhoods, and community facilities, both well and ill.

Nursing programs contribute to the efficiency of the health care sector. every day nurses are regarded as one of the health delivery providers; nurses as employees of the health delivery community must offer optimal and coordinated treatment to every day nursing staff are required to be able to fulfill the demands and expectations of health services (Sarayar \& Kewas, 2017). The efficacy of a nurse-directed nursing care can be obtained, one of which depends on the working-force/work-load of nurses in a hospital.

distinct biopsychosocial work performed 24 hours a day is a day has a distinct benefit of quality healthcare; they also, nurses have an important role in the healthcare industry, because of their services being delivered based on a biopsychosensibly; additionally, they play a key role in the hospital's care because of the special biopsychosocial model (Effendy, 1998).

In staff planning, clinics and other than the hospitals offering healthcare services should be taken into consideration when doing so as as not not have an effect on patient safety or human 
capital, which can result in lowered levels of care. poorly planned work will contribute to nurse problems as well as additional and considerable workload and lower productivity/satisfaction (Potter \& Perry, 2010).

If a patient's desires are met, then the quality of nursing care or the satisfaction of those services is measured. degree of happiness varies, no one is entitled to an infinite amount of it (Nursalam, 2014). By comparison, patient frustration is a direct product of substandard health treatment.

Nursing is defined as a type of clinical service that is an integral part of health services focused on nursing skills and tips, in the form of holistic bio-psycho-socio-spiritual services to individuals, families, and communities, both sick and well, covering the entire cycle of human life, according to the Ministry of Health of the Republic of Indonesia. Nurses give personal care to patients and regard them as humans through this nursing service.

In health-care agencies, nurse efficiency is a significant concern. In order to improve the quality of health care, increasing the effectiveness and success of health staff is critical. Knowledge, expertise, and inspiration, as well as a positive working climate, all affect a health worker's success. According to the findings of a survey performed in Namibia (Africa) on the variables that affect the success of practicing nurses, 38.1 percent of the 180 nurses in the study samples, both from government and private hospitals, had their performance not been measured, and if it was, it would be done informally. The nurse's performance assessment is not seen as a criterion for attempts to increase work performance and advance throughout her career (Awases et al., 2013).

According to the findings of a survey conducted by the Indonesian National Nurses Association (PPNI) in 2006, approximately 50.9 percent of nurses working in four Indonesian provinces reported poorer quality performance due to work pressures, often feeling dizzy and exhausted, and unable to rest due to workloads. too time-consuming and slow, and poor wages with inadequate rewards (Nursalam, 2014).

The most debated challenge, according to the PPNI (Indonesian National Nurses Association) in Central Java, is an inequality of benefits or rewards between classes of physicians, nurses and the equivalent of nurses, administrative personnel, and hospital manager ranks, which leads to sustained tension and lower results. Aside from nurses, there are various other influences that impact efficiency. Internal organizational environmental factors, external environmental factors, and internal factors of employees or employees are all variables that impact a person's performance (Wirawan, 2015).

The effect that happens if hospital nurses work poorly, causing patients and/or their families to be disappointed, patients and/or their families will not use health care again, and this will have an impact on hospital income, which will decline due to a negative reputation hospitals have in the community (Khamida \& Mastiah, 2015).

Nurses' bad performance will result in patients' wishes and desires not being met, the disease curing process taking longer, and other hospitals' competition being harmed. One of the most important things to work on is enhancing quality efficiency, because without trained nurses, no matter how advanced the current structure is, the hospital's vision, mission, and priorities would be difficult to accomplish.

Deli Serdang Regional General Hospital is the only General Hospital operated by the Government of Deli Serdang Regency, is a Service Referral Center with Class B Non Education status based on the Decree of the Minister of Health of the Republic of Indonesia Number 405 / MENKES / IV / 2008 dated April 25, 2008, and has achieved Full Accreditation of 16 Facilities in 2011 according to the Decree of the Minister of Health of the Republic of 
Indonesia Number 405 / MENKE Deli Serdang Hospital's Organizational Structure Number I of 2014, March 5, 2014. In compliance with Government Regulation Number 18 of 2016 and Perda Number 3 of 2016, the Deli Serdang Regional Hospital was founded as an autonomous entity under the UPT Health Service in the form of a Regional Public Service Agency (BLUD). KARS awarded us a 4 star key level on December 30, 2016, with the following number: KARSSERT / 361 / X11 / 2016 as a Type B Hospital based on KEPMENKES RI NUMBER: 405 / MENKES / SK / IV / 2008. Deli Serdang Hospital aims to be the FK UMSU Only Teaching Hospital in 2017.

According to Nursalam (2007), the nurse-to-patient ratio in the Case Specialist Nursing Care Model (MAKP Case) is 1: 1, while the nurse-to-patient ratio in the Primary Team Professional Nursing Model (MAKP Team-Primary) is 1: 4 or 1: 5.

According to data from the Deli Serdang Regional General Hospital, there were 12,220 inpatients in 2015, with a Bed Occupancy Rate (BOR) of 78.3 percent. With 256 available beds split into 15 inpatient rooms, the number of inpatients rose by 13,534 people in 2016 , resulting in a BOR of 86.89 percent.

The nursing staff at Deli Serdang Hospital totals 283 employees, with 191 nurses working in the inpatient facility. According to Permenkes No.56 / MENKES / PER / III / 2014, the ratio of nursing staff to beds in a class B hospital is 1: 1 . The ratio between the number of nurses and the correct sleep was 191:256 based on the available data.

We can see from the aforementioned statistics that there is a difference between the number of medical nurses and the monthly total number of inpatients, which would impact nurses' capacity to deliver high-quality clinical services to patients. Patient satisfaction with the work of nurses, specifically those who use care in the inpatient space, is one of the most significant variables for patient survival in terms of choosing to use certain medical services or allowing others to use the hospital's services.

According to the context definition, conducting studies in order to analytically assess the success of nurses based on patient expectations is critical. Poor nursing services to patients can lead to feelings of dissatisfaction for patients, causing many patients to be disappointed with health services, causing patients to think about receiving health services more often, especially in hospitals, causing hospital revenue to decline, poor people's health to deteriorate, and the emergence of a negative perception of a profession, including nursing. Since nursing is an occupation that involves delivering clinical care, it is not unusual for patients to express disappointment with nursing services.

Satisfaction is a feeling of satisfaction or dissatisfaction that happens when one's experiences or observations of a product's success or outcomes are relative to their expectations. Consumer loyalty comes from the level of treatment rendered by the patient, which is what the healthcare provider has done for the patient as a care service connected to the recovery phase of the patient's disease and patient care consistency whilst in the hospital. In order to achieve customer retention in a business or hospital, businesses or hospitals must develop and maintain a structure in order to attract and retain customers.

The success of nurses who deliver care to patients has a strong association with satisfaction. According to Nursalam, there are five indicators of patient satisfaction that are used as indicators in this study: tangibles in the form of physical facility appearance, reliability (reliability) in the form of nurses' ability to deal with problems quickly, responsibility (responsiveness) in the form of nurses' willingness to help patients when they are experiencing difficulties, assurance (assurance) in the form of nurses' willingness to help patients when they 
are experiencing difficulties, and assurance (assurance) in the form of nurses' willingness to help patients when they are experiencing difficulties.

According to Kambong et al (2013), patient frustration is caused by a disconnect between the patient's preferences and the quality of health-care services received. Mulyono et al. (2013) found that competency, work satisfaction, commitment, management, and leadership variables did not have a major impact on nurse success when tested in an ultivariate way with regression tests.

According to the findings of a survey of patient attitudes conducted in October 2018, $70 \%$ of patients reported dissatisfaction with the health care they received, specifically in terms of nurses' reactions to sluggish patient concerns, unfriendly nurses, and ineffective contact with patients and families. The Deli Serdang Regional General Hospital has made efforts to provide resources for nurses to continue their education and training in turn, as well as attend seminars and training according to work schedules, but nurse efficiency remains poor.

Nurses were also unable to deliver the best nursing care to patients, according to the findings of the initial survey undertaken in November in hospitalization, due to a lack of work enthusiasm and knowledge of nurses' work status as a health service role. This is based on the findings of a direct observation by researchers at the hospital, who interviewed 5 nurses in the inpatient room about their high workload and lack of attention from their superiors to work performance achieved, and there was little difference in incentives received between those who were diligent and those who were lazy to work, and promotion has not been adjusted. Nurses also like to shift employers because their monthly pay does not meet their needs.

Based on the above, the researcher is interested in investigating the relationship between nurse success and patient satisfaction in the Deli Serdang Regional General Hospital's inpatient unit. The aim of this research was to see whether there was a connection between nurse success and patient satisfaction in the Deli Serdang Regional General Hospital's inpatient unit.

\section{Methods}

The aim of this analysis was to classify and assess the success of nurses in the inpatient room of the Deli Serdang Regional General Hospital using a survey methodology with a cross sectional approach. A survey, according to Singarimbun, is an analysis that is carried out on both large and small groups, but the data studied is data from a sample (Singarimbun \& Effendi, 1989).

The study took place in the Deli Serdang Regional General Hospital's inpatient unit between May and June of this year. The population in this sample consisted of all 320 patients in the Deli Serdang Regional General Hospital's Inpatient Space. Purposive screening, which included as many as 77 patients, was used in conjunction with the study goals. Univariate and bivariate regression were used to analyze the results. The characteristics of each independent variable and the dependent variable were defined using univariate data analysis. Using the Chisquare measure, bivariate regression was used to show that there was no meaningful relationship between the independent variables and the dependent variable. The logistic regression test was used to assess the effect of independent variables on the dependent variable in multivariate data analysis.

\section{Results and Discussion}

Table 1 shows the distribution of respondents' response groups. Of the 77 people who responded, $44(57.1 \%)$ thought nurse care were of poor quality. According to the distribution of respondents' response groups, 42 out of 77 people (54.5 percent) thought nurse contact was poor. According to the distribution of respondents' response types, as many as 40 people 
(51.9\%) felt the nurse's pace was not nice. According to the distribution of respondents' response groups, 33 people (42.9 percent) felt that nurses' skills were not strong. According to the distribution of respondents' response groups, 32 people $(41.6 \%)$ thought the nurse's initiative was not nice. Furthermore, according to the distribution of respondents' response groups, 46 people $(59.7 \%)$ thought nurse services were of poor quality.

\section{Bivariate Analysis}

Based on the cross tabulation findings, it can be found that while 77 respondents $(100 \%)$ viewed the standard of nurse care as "Not Fine," 44 respondents $(57.1 \%)$, including 3 people (3.9\%) who were pleased, and 41 other respondents $(53,2 \%)$ who were "Not satisfied" with the quality of service. Meanwhile, 33 respondents (42.9\%) viewed the service standard as "Good," with 28 respondents $(36.4 \%)$ "Satisfied" and 5 respondents $(6.5 \%)$ "Not Satisfied" with nurse services. The value of value $(0,0000.05)$ was derived based on the findings of the chi-square statistical test, indicating that there is an association between service efficiency and patient satisfaction in the inpatient room of the Deli Serdang Regional General Hospital in 2019.

According to the findings of the cross tabulation, 77 respondents $(100 \%)$ classified the nurse contact as "Not Good," while 42 respondents $(54.5 \%)$ rated the nurse communication as "Satisfied," with 4 individuals (5.2 percent) "Satisfied" and 38 (49.4\%) other respondents "Not Satisfied." Meanwhile, 35 respondents (45.5\%) classified nurse contact as "Good," with 27 respondents $(35.1 \%)$ rating it as "Satisfied" and eight respondents $(10.4 \%)$ rating it as "Not Satisfied." The value of value $(0,0000.05)$ was obtained based on the findings of the chi-square statistical test, indicating that there was an association between contact and patient satisfaction in the inpatient room of the Deli Serdang Regional General Hospital in 2019.

According to the results of cross tabulation, 77 respondents (100\%) classified the pace of nurses as "Not Good," while 40 respondents $(51.9 \%)$ rated the speed of the nurse as "Satisfied," with three individuals (3.9 percent) "Satisfied" and 37 other respondents $(48.1 \%)$ "Not Satisfied." Meanwhile, 37 respondents (48.1 percent) rated the pace of nurses as "Healthy," with 28 respondents (36.4 percent) rating it as "Satisfied" and 9 respondents (11.7 percent) rating it as "Not Satisfied." Based on the effects of the chi-square statistical test, a value of 0,000 was obtained, and hence the value of $(0,000>0.05)$, indicating that there is an association between pace and patient satisfaction in the Deli Serdang Regional General Hospital's inpatient room in 2019.

According to the cross tabulation findings, there were 77 respondents $(100 \%)$ who viewed the level of nurse care as "Not Well," as well as 33 respondents (42.9\%), including 2 individuals $(2.6 \%)$ who classified the service as "Satisfied," and 31 other respondents. Nurses' abilities are "unsatisfactory" in 40.3 percent of cases. Meanwhile, 44 people $(57.1 \%)$ rated nurses' skills, with $29(37.7 \%)$ reporting they were "satisfied" and $15(19.5 \%)$ saying they were "not satisfied." Based on the effects of the chi-square statistical test, a value of 0,000 was achieved, and hence the value of $(0,0000.05)$, indicating that there was a relationship between nurse capacity and patient satisfaction in the Deli Serdang Regional General Hospital's inpatient room in 2019.

According to the cross-tabulation findings, 77 respondents (100\%) classified the nurse's initiative as "Not Well," while 32 respondents (41.6\%) rated the nurse's initiative as "Satisfied," with 11 people (14.3 percent) "Satisfied" and 21 other respondents (27.3 percent) "Not Satisfied." Meanwhile, 45 respondents (58.4 percent) felt nurses' initiative was "healthy," with 20 respondents (26.0 percent) "satisfied" and 25 respondents (32.5 percent) "not satisfied" with the initiative. Based on the findings of the chi-square statistical exam, a value of 0.000 was achieved, and hence the value of $(0.4810 .05)$, indicating that there was no association between 
service efficiency and patient satisfaction in the Deli Serdang Regional General Hospital's inpatient room in 2019.

Table 1.Frequency Distribution of Respondents Based on Service Quality, Communication, Speed, Ability, Initiatives and Patient Satisfaction

\begin{tabular}{|l|c|c|}
\hline \multicolumn{1}{|c|}{ Variable } & Number (n) & Percentage (\%) \\
\hline $\begin{array}{l}\text { Quality of Nurse Services } \\
\text { Not Good }\end{array}$ & 44 & 57,1 \\
\hline Good & 33 & 42,9 \\
\hline Nurse Communication & 42 & 54,5 \\
\hline Not Good & 35 & 48,1 \\
\hline Good & & \\
\hline Speed Nurse & 40 & 51,9 \\
\hline Not Good & 33 & 42,9 \\
\hline $\begin{array}{l}\text { Nurse Skills } \\
\text { Not Good }\end{array}$ & 44 & 57,1 \\
\hline Good & 32 & 41,6 \\
\hline Nurse Initiative & 45 & 58,4 \\
\hline Not Good & & 59,7 \\
\hline Good & 46 & 40,3 \\
\hline Patient Satisfaction & 31 & \\
\hline Dissatisfied & & \\
\hline Satisfied & & \\
\hline
\end{tabular}

Table 2. Crosstabulation between Service Quality, Communication, Speed, Capability and Initiative with Patient Satisfaction

\begin{tabular}{|c|c|c|c|c|c|c|c|}
\hline \multirow{3}{*}{ Variable } & \multicolumn{4}{|c|}{ Patient Satisfaction } & \multirow{2}{*}{\multicolumn{2}{|c|}{ Total }} & \multirow{3}{*}{$\begin{array}{c}\rho \\
\text { value }\end{array}$} \\
\hline & \multicolumn{2}{|c|}{ Satisfied } & \multicolumn{2}{|c|}{ Dissatisfied } & & & \\
\hline & $\mathbf{n}$ & $\%$ & $\mathbf{n}$ & $\%$ & $\mathbf{n}$ & $\%$ & \\
\hline Quality of Nurse Services & & & & & & & \multirow{3}{*}{0,000} \\
\hline Not Good & 3 & 3,9 & 41 & 53,2 & 44 & 57,1 & \\
\hline Good & 28 & 36,4 & 5 & 6,5 & 33 & 42,9 & \\
\hline Nurse Communication & & & & & & & \multirow{3}{*}{0,000} \\
\hline Not Good & 4 & 5,2 & 38 & 49,4 & 42 & 54,5 & \\
\hline Good & 27 & 35,1 & 8 & 10,4 & 35 & 45,5 & \\
\hline Speed Nurse & & & & & & & \multirow{3}{*}{0,000} \\
\hline TidakBaik & 3 & 3,9 & 37 & 48,1 & 40 & 51,9 & \\
\hline Good & 28 & 36,4 & 9 & 11,7 & 37 & 48,1 & \\
\hline Nurse Skills & & & & & & & \multirow{3}{*}{0,000} \\
\hline Not Good & 2 & 2,6 & 31 & 40,3 & 33 & 42,9 & \\
\hline Good & 29 & 37,7 & 15 & 19,5 & 44 & 57,1 & \\
\hline Nurse Initiative & & & & & & & \multirow{3}{*}{0,481} \\
\hline Not Good & 11 & 14,3 & 21 & 27,3 & 32 & 41,6 & \\
\hline Good & 20 & 26,0 & 25 & 32,5 & 45 & 58,4 & \\
\hline
\end{tabular}

\section{Mulivariate Analysis}

Based on multivariate findings using multiple logistic measures, it was discovered that the value of $\mathrm{p}=0.016$ and $\mathrm{p}=0.0160 .05$, respectively, obtained from the predictor output of nurses 
(quality of care and communication), dramatically affects the satisfaction of patients in the inpatient room at Deli Serdang Regional General Hospital because of the value of p0.05.

Table 3. Logistics Regression Multivariate Test Results

\begin{tabular}{|l|c|c|c|}
\hline \multicolumn{1}{|c|}{ Independent Variables } & B & P Value & Exp (B) \\
\hline Quality of Nurse Services & 3,692 & 0,016 & 40,129 \\
\hline Nurse Communication & 5,494 & 0,016 & 243,257 \\
\hline Speed Nurse & 5,182 & 0,043 & 178,048 \\
\hline Nurse Skills & 3,809 & 0,042 & 45,083 \\
\hline Nurse Initiative & $-6,491$ & 0,058 & 0,002 \\
\hline Constant & $-7,367$ & 0,002 & 0,001 \\
\hline
\end{tabular}

\section{Effect of Service Quality on Patient Satisfaction}

The level of service is critical to consider because it can influence how customers view products and services when they have used them. Due to the recent increase in rivalry, a business company or service provider must still pamper customers by offering the best service.

According to the findings, 77 respondents (100\%) classified the quality of nurse care as "Not Fine," while 44 respondents $(57.1 \%)$ rated the quality of service as "Not Satisfactory," with three individuals (3.9\%) pleased and 41 others (53.2\%) "Not Satisfied." Meanwhile, 33 respondents (42.9\%) classified the standard of service as "Good" and 33 respondents $(42.9 \%)$ rated it as "Excellent" (42.9 percent) The standard of nursing care was rated "Satisfied" by 28 respondents (36.4\%) and "Not Satisfied" by 5 respondents (6.5\%). And the chi-square statistical test yielded a value of 0.000 or 0.05 ), suggesting that there is a correlation between service quality and patient satisfaction in the Deli Serdang Regional General Hospital inpatient room in 2019.

The sig-p 0.0160 .05 value for variable quality of care indicates that the quality of service has a substantial impact on patient satisfaction in the inpatient room at Deli Serdang Regional General Hospital in 2019. The findings of the Odd Ratio of variable service quality with OR 40,129ka show that high connectivity has a 40,129 times greater impact on patient satisfaction than poor service quality. B is the normal logarithm of 40.129 , which equals 3.692. Since B has a positive benefit, service quality has a positive impact on customer satisfaction.

Patients would be happier if the findings of their assessment indicate that the product or service they got was of good quality. The reality of the nature of poduk or actual facilities, as well as corporate communication, especially advertisement in promoting the hospital, influence customer expectations of poduk or services.

The disparity between what consumers want and what they get from service providers determines the consistency of p elayanan. The aspiration of customers for the service they offer is hope. A quality's attention is on the customer. If a product meets the needs of the consumer, it is considered to be of high quality. Quality often applies to something that will satisfy consumers (Kotler \& Keller, 2006).

Andriani (2009) published study with the title "Relationship of Health Service Quality with Inpatient Satisfaction in The Health Service Agency of Magelang District General Hospital." The findings revealed that 159 people participated in the service quality study ( 83 percent ) 79 people (41 percent) expressed great satisfaction and 19 people (10 percent) reported quite satisfied with the value $\mathrm{p}$ value $=0.001$ or 0.05 , while the findings from the inpatient satisfaction study data revealed that 79 people (41 percent) expressed great satisfaction and 19 people (10 percent) stated quite satisfied with the value $\mathrm{p}$ value $=0.001$ or 0.05 . 
The study "Relationship of Quality Nursing Services with Inpatient Satisfaction at Rachma Husada Bantul HospitalYogyakarta" by Leni Fitia was published in 2017. The findings of a survey in which a significant number of patients rated the quality of nursing services at Rachma Husada Bantul Hospital as strong 47 (63.5 percent). The majority of inpatient satisfaction ratings at Rachma Husada Bantul Hospital is in the high 56 percentile (73.0 percent). At Rachma Husada Bantul Hospital, there is a significant association between the quality of nursing care and inpatient satisfaction, with a relationship density of 0 . (43.8 percent).

According to study, there are so many patients who are dissatisfied with the consistency of nurse care, where nurses are still missing in intervention and responding to patients in a timely manner, so this contributes to the patient's disappointment with the nurse service.

\section{Effect of Nurse Communication on Patient Satisfaction}

One of the reasons for patient problems in hospitals is a lack of contact between nurses and patients. Patients also demonstrate frustration with the consistency and quantity of information obtained by health care services. The patient's reaction to the appraisal of perceived disappointment between goals is called fulfillment or dissatisfaction.

The findings found that out of 77 respondents (100\%) who viewed nurse contact as "Not Well," 42 respondents $(54.5 \%)$ were "Satisfied" with the nurse's communication, with four people (5.2\%) being "Satisfied" and 38 (49.4\%) being "Dissatisfied." Meanwhile, 35 respondents (45.5\%) classified contact as "strong." The nurse's contact was rated "satisfactory" by 27 respondents $(35.1 \%)$ and "unsatisfactory" by 8 respondents $(10.4 \%)$. According to the findings of the chi-square statistical test, which yielded a value of 0.000 or 0.05 , there is a correlation between contact and patient satisfaction in the Deli Serdang Regional General Hospital inpatient room in 2019.

Contact has a sig-p value of 0.0160 .05 in the inpatient room at Deli Serdang Regional General Hospital in 2019, indicating that communication has a major impact on patient satisfaction. When the Odd Ratio of vector contact is 243,257 , it means that high communication has a 243,257 -fold effect on patient satisfaction when opposed to low communication. The natural logarithm of 243.257 equals 5.494. Contact has a positive effect on patient satisfaction since the importance of $\mathrm{B}$ is positive.

Nursing programs are an essential aspect of patient care in hospitals and other support environments. Quality nursing facilities are one of the metrics used to measure the quality of a health service because nursing is such an important aspect of it (Khotimah, 2012).

Nursing managers' tasks provide a great deal of communication. Nurses as communicators and patients as communion are critical to the efficacy of contact in enhancing patient satisfaction. Contact is effective in addressing critical needs in the hospital, and nurses should be aware of this.

According to study, contact between nurses and patients is not well known, with nurses unable to have communicative communication and patients that are easy to understand. Patients did not obtain accurate guidance from nurses, who did not give comprehensive descriptions or provide attraction to patients in a good way of communicating, according to the researchers.

\section{The Effect of Nurse Speed on Patient Satisfaction}

Individuals, households, associations, and neighborhoods with health conditions benefit from the services offered by nurses. The services given are attempts to maintain the highest quality of wellbeing in line with the ability that the nursing process as a research system of nursing has of carrying out practices in the fields of promotion, prevention, curative, 
and rehabilitative nursing. Nursing treatment is provided by nurses in partnership with other health care professionals in order to ensure optimum health.

According to the results, 77 respondents $(100 \%)$ rated the speed of nurses as "Not Good," while 40 respondents $(51.9 \%)$ rated the speed of the nurse as "Satisfactory." Three respondents $(3.9 \%)$ rated the speed of the nurse as "Satisfactory," while 37 others $(48.1 \%)$ rated it as "Not Satisfactory." Meanwhile, 37 respondents $(48.1 \%)$ graded the speed of "Good" nurses as "Good," with 28 respondents (36.4\%) rating the speed as "Satisfied," and 9 respondents $(11.7 \%)$ rating the speed of the nurse as "Not Satisfied." There is a relationship between pace and patient satisfaction in the inpatient room of Deli Serdang Regional General Hospital in 2019, according to the findings of the chi-square statistical test (value of 0.000 or 0.05 ).

The vector pace has a sig-p value of 0.0430 .05 , indicating that speed has a substantial impact on patient satisfaction in the Deli Serdang Regional General Hospital's inpatient room in 2019. The pace variable's Odd Ratio outcome of OR 178.048 indicates that high contact has a 178.048 times greater impact on patient satisfaction than low communication. 5,182 is the natural logarithm of 178,048 . Speed has a positive impact on patient satisfaction since the value of $B$ is positive.

Employee readiness to assist clients to provide fast and attentive support includes: employee readiness to serve customers, employee pace in handling sales, and employee speed in handling customer/patient grievances.

This highlights the proportional conduct that offers services to pay attention to queries, demands, and closeness from consumers. Speed / accessibility is the willingness to support and deliver swift and accurate service to customers with clear facts. Speed and responsiveness, such as nurses' ability to respond quickly to patient requests, officers' ability to provide simple and understandable facts, and prompt actions when patients are in need.

According to the researcher's conclusions, there are also nurses who are slow in carrying out their tasks and behavior with patients. For example, if a patient request anything, the nurse is slow to respond. The researchers have discovered that certain nurses were already doing it slowly, such as adjusting the infusion.

\section{Effect of Ability on Patient Satisfaction}

The prescribing nurse is the one who does the most actions; for example, if the patient needs intravenous treatment, the nurse will typically mount an intravenous line and deliver the necessary fluids and drugs; if the patient requires injection, the nurse will administer it; in this situation, the patient must be able to conduct the operation.

The findings revealed that while 77 respondents (100\%) viewed the level of nurse care as "Not Well," 33 respondents (42.9 percent) rated the ability of nurses as "Satisfied," with two people (2.6 percent) "Satisfied" and 31 others (40.3\%) "Not satisfied." Meanwhile, 44 people $(57.1 \%)$ rated nurses' skills, with $29(37.7 \%)$ reporting they were "satisfied" and 15 $(19.5 \%)$ saying they were "not satisfied." There was an association between the capacity of nurses and patient satisfaction in the inpatient room of the Deli Serdang Regional General Hospital in 2019, according to the findings of the chi-square statistical test (value of 0.000 or 0.05$)$.

The capacity variable has a sig-p value of 0.0420 .05 , suggesting that it has a substantial effect on patient satisfaction in the Deli Serdang Regional General Hospital's inpatient room in 2019. The skill variable's Odd Ratio outcome of OR 45.083 indicates that high 
ability has a 45.083 times greater impact on patient satisfaction than low ability. Price $\mathrm{B}=$ 45.083 Natural Logarithm $=3.809$. Ability has a positive influence on patient satisfaction because its value is positive.

Ability refers to a collection of qualities or attributes exhibited by workers who succeed in their careers. Customer needs must be met, which implies punctuality, providing the same level of quality to all consumers without defects, a sympathetic demeanor, and high precision. Ability to deliver facilities in accordance with their level of expertise, consistency in mastering the applicable work field in accordance with their abilities, consistency in mastering the work field in accordance with their work experience, and the ability to use current work technologies (Nasyrah \& Darwis, 2017).

Ability also requires the ability to uphold promises (on time, consistency, speed, in service). The delivery of service commitments would be connected to and represent the company's service reputation. The durability, or the degree to which the company's skill level can be shown, can also indicate the level of competence (Smith, 2012). The probability or expectation of a product fulfilling its function effectively in a specified time span under specific circumstances is referred to as reliability. As a result, reliability is a quality that indicates the possibility or chance of success.

According to the researcher's findings, there are still nurses with limited skills. According to experts, this is attributed to the hospital's shortage of experience for nurses, resulting in the nurses' inability to carry out actions.

\section{Effect of Initiatives on Patient Satisfaction}

Someone's effort is linked to their ability to reason, as well as their imagination in the form of ideas for achieving corporate goals. If the manager is a good boss, any initiative should receive attention or a supportive response. Bad managers will often hinder ambition without rewarding it with simple and supportive reasons, allowing the company to lose its momentum and drive to move forward. In other words, within the company, employee efforts are a guiding force for change, and will eventually impact results.

The findings revealed that while 77 respondents (100\%) viewed the nurse's initiative as "Not Good," 32 respondents (41.6\%) rated it as "Satisfactory," with 11 people (14.3\%) "Satisfied" and 21 others $(27.3 \%)$ "Not Satisfied" with the nurse's initiative. Meanwhile, 45 respondents (58.4 percent) rated the nurses' program as "satisfactory," while 25 respondents (32.5 percent) rated it as "unsatisfactory." There was no association between service quality and patient satisfaction in the inpatient room of the Deli Serdang Regional General Hospital in 2019, according to the findings of the chi-square statistical test (value of 0.481 or 0.05 ).

The contact indicator has a sig-p value of 0.0580 .05 , suggesting that the initiative has no major effects on patient satisfaction in the Deli Serdang Regional General Hospital's inpatient room in 2019. As opposed to low initiatives, high measures had a 0.002 times greater effect on patient satisfaction. B's value is 6.491 , which is the normal logarithm of 0.002 . Since B has a negative meaning, the program has little positive effects on patient satisfaction.

So that infertility does not arise at work, each employee must be able to solve his or her own work problems. Nurse efficiency is a method or sequence of actions that nurses participate in when working with patients in conjunction with their tasks, careers, and obligations (McIntosh et al., 2015). In the sense of addressing health challenges, the process of nursing care approaches that are empirical, systemic, and ongoing as well as continuous. 
Nursing programs are specialized services provided as part of health care to patients, families, organisations, or neighborhoods, whether safe and ill, based on nursing experience and tips (Law on Nursing No. 38 of 2014).

The happiness of patients who are being or have been served, which is an expression of relaxation or enjoyment that the expectation of a patient's needs is met by nursing services, which when defined means satisfaction with ease, pace, service, friendliness, and attention, is used to measure the quality of nursing facilities or the performance of nurses in a hospital. Meanwhile, happiness has a relative value that varies from person to person (Natsir, 2008). Consumer disappointment, on the other hand, is induced by fewer skilled health staff, in the sense that nurses delivering nursing care are unable to satisfy any of the patient's needs.

\section{Conclusion}

Patient satisfaction is determined by service quality, connectivity, tempo, and capacity, according to the results of this report. The findings of this research are intended to increase the quality of nursing care and patient contact, be non-harmful to patients, and provide nurses with instructions to act diligently while treating patients so that patients are pleased with the quality of medical services.

\section{Thank-You Note}

Researchers would like to thank the Director of the Deli Serdang Regional General Hospital for providing the opportunity, place, time and direction to researchers to carry out this research.

\section{References}

Aditama, T. Y. (2002). Manajemen administrasi rumah sakit. Penerbit Universitas Indonesia.

Awases, M. H., Bezuidenhout, M. C., \& Roos, J. H. (2013). Factors affecting the performance of professional nurses in Namibia. curationis, 36(1), 1-8.

Effendy, N. (1998). Dasar-dasar keperawatan kesehatan masyarakat. EGC.

Khamida, K., \& Mastiah, M. (2015). Kinerja Perawat Dalam Memberikan Asuhan Keperawatan Berpengaruh Terhadap Kepuasan Pasien Rawat Inap. Journal of Health Sciences, 8(2).

Khotimah, N. (2012). Hubungan Komunikasi Terapeutik Perawat Dengan Kepuasan Pelayanan Keperawatan Di Ruang Inayah Rumah Sakit Pku Muhammdiyah Gombong. Jurnal Ilmiah Kesehatan Keperawatan, 8(2).

Kotler, P., \& Keller, K. L. (2006). Marketing Management 12e. France: Edition Pearson Education.

McIntosh, B., McQuaid, R., \& Munro, A. (2015). The impact of gender perceptions and professional values on women's careers in nursing. Gender in Management: An International Journal.

Nasyrah, N., \& Darwis, D. (2017). Analisis Pengaruh Dimensi Kualitas Pelayanan Terhadap Kepuasan Pasien Rawat Inap Di Rumah Sakit Bhayangkara Makassar. Jurnal Mirai Management, 2(1), 133-148.

Nursalam, D. (2014). Manajemen Keperawatan" Aplikasi dalam Praktik Keperawatan Profesional. Stikesrspadgs.

Potter, P. A., \& Perry, A. G. (2010). Fundamental Keperawatan, Book 3. Retrieved at: repo.unikadelasalle.ac.id. 
Sarayar, C., \& Kewas, E. S. (2017). Hubungan Kualitas Pelayanan Keperawatan Dengan Tingkat Kepuasan Pasien Rawat Inap Di Puskesmas Poigar Kabupaten Bolaang Mongondow. Journal Of Community and Emergency, 5(2), 22-33.

Singarimbun, M., \& Effendi, S. (1989). Metode Penelitian Survei, Jakarta. Kegiatan Wisata Bahari di Resort Pengelolaan Wilayah Pulau Harapan Taman Nasional Kepulauan Seribu.

Smith, S. A. (2012). Nurse competence: a concept analysis. International journal of nursing knowledge, 23(3), 172-182.

Wirawan, A. (2015). Evaluasi Kinerja Sumber Daya Manusia. Teori Aplikasi dan penelitian, Salemba Empat, Jakarta. 